\title{
The Basic Aspects of the Failures Resulted in the Failure of the Construction
}

\author{
Meizy Amariza*, Hadri Mulya \\ Magister Mercu Buana University, Master of Accounting, Meruya Selatan Road, West Jakarta, Indonesia Jakarta, Indonesia
}

DOI: $10.36348 / \mathrm{sb} .2019 . v 05 \mathrm{i} 11.008$

| Received: 19.11.2019| Accepted: 26.11.2019 | Published: 28.11.2019

*Corresponding author: Meizy Amariza

\section{Abstract}

This research uses a quantitative method with descriptive analysis that focuses on the study of construction projects from the phenomenological side by using the thoughts of prominent figures including sevilary demirkesen, Beliz Ozorhon,and Eroshkin. By using qualitative collection methods by interviewing informants to get a conclusion. The results of exploration show that many factors influence the success of the construction. One of them is project management. The role and function of operational management can be used as a benchmark for the level of effectiveness and efficiency in terms of using the project budget. The achievement of the level of success of the implementation of construction operational management functions must be accompanied by the application of the company's internal control system (SPI) in an optimal manner, to avoid construction failure. Where the success and failure of the basic aspects above will have an impact on the quality of the company's financial statement

Keywords: Application of Construction Operational Management Functions, Determine the level of effectiveness and Efficiency in the Use of Project Budgets and Implementation of internal control systems (SPI), Quality of Financial Statements.

Copyright @ 2019: This is an open-access article distributed under the terms of the Creative Commons Attribution license which permits unrestricted use, distribution, and reproduction in any medium for non-commercial use (NonCommercial, or CC-BY-NC) provided the original author and source are credited.

\section{INTRODUCTION}

In accordance with the current technological advances as well as the development of the process of development in various fields, have made their scholars and experts design capable of competing in the race for development and their imagination to develop and design in specific building skyscrapers in order to beautify the capital. In the process of developing a building of an enterprise, the need for a wide variety of strategies that are owned to be able to win the competition in an industry, including industrial property. A company that is run without a strategy, then it can certainly cause problems for winning the competition was very tight at the moment.

In general the implementation of construction projects that will be done either in the process of the construction of a multi-storey building, the process of construction of highways or any process related to the construction of only a few involve parties that are considered highly influential in the process of implementing the development among his is the owner where the owners here is the giver of contracting duties and funds in the development process without the owners of course development will not be created, the two designers and the third is a construction contractor. Where the three have a very influential role in the development process and the third of his roles against a development life cycle as articulated by Marzuki [1] in the news his research entitled Construction management for facilities woke up a nation. The construction carried out by scholars and experts design the construction referred to with a project. SCHWALBE translated by Dimyati \& Nurjaman [2] explained that the project is a temporary endeavor to produce a unique product or service.

Factor that affects success in development construction projects. One of these is project management. "Management is the process of (a) planning, (b). Organizing (c) leadership, and (d) control efforts using all members of the organization and the Organization's resources to achieve its intended purpose, that is to say Management is a process planning, organizing, leadership and control effort by use of all Member organizations and organizational 
resources to achieve the goals that have been set. Stoner and Daniel [3]. Construction management focuses more on:

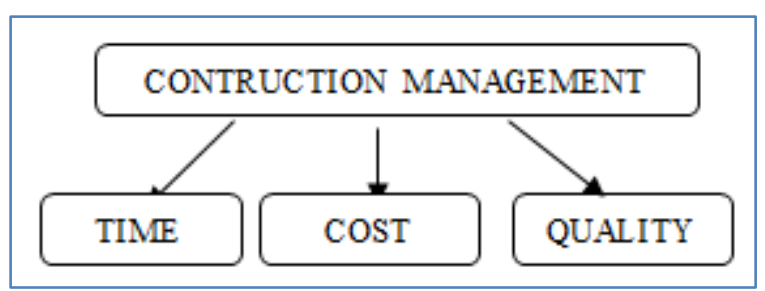

Source: Winoto, 2014:02

In the implementation of project management this is a very basic key for companies to target achievement of success, With how to perform the functions of the operational management of the construction that has been applied in theory and if its application was implemented in the development process. There are four functions of management are expressed, among others, is a Management is a set of activities (a) including Planning (b) the planning decision making, (c) lead (d) and control) are directed to the Organization's resources (human, financial, physical and information) to override the Organization (goal), (Efficient), and the (effective), Griffin [4].

If the four management functions above are implemented properly in a development process, the implementation of the project can be said to be achieved. The application of management functions in the company greatly affects the life cycle of the project management that has been set. Image of construction management life cycle. (Life cycle of infrastuktur project management).

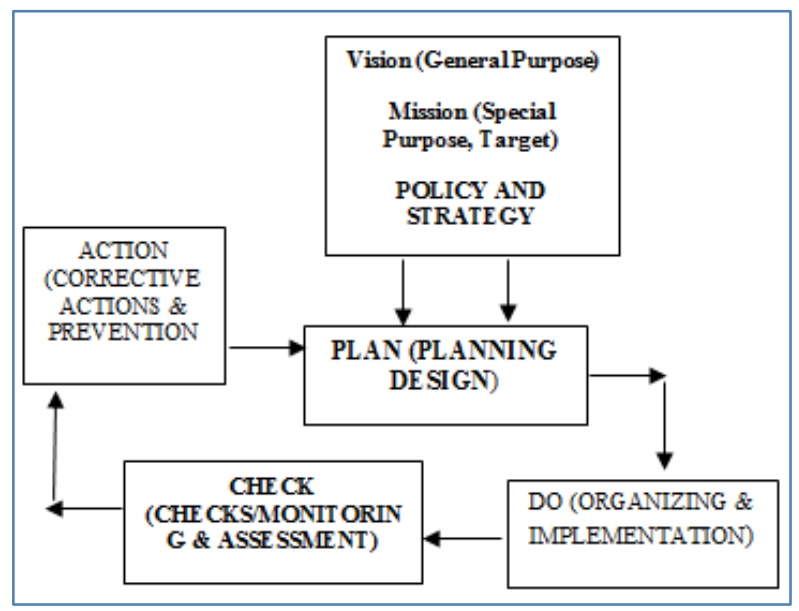

Source Soeharto, 2013

This is related to Demirkesen's statement in his research [5] which states that "The performance of construction projects depends on different project management dimensions. The importance because effective project management starts with the integration of processes and people in a construction project. The proposed component in management integration is the development of a project charter, knowledge integration, process integration, staff integration, supply chain integration and change integration; while the dimensions of project management performance are time, cost, quality, safety, and client satisfaction.

To know the success of the operation the function of the management company here must know first the role and objectives of project management were defined. Construction project management has been considered the leading guide to all aspects of construction project management process, including the critical path method (CPM) scheduling the project, and more Sears [6]. To achieve management objectives it is not easy where companies must also implement a monitoring system for quality, cost and time. This must be done by the company so that all processes related to operational activities in project development can run smoothly and smoothly as expected. Management objectives set must be in accordance with existing management functions. The main purpose of management is to manage the function of management functions in such a way that the results obtained are optimal in accordance with the requirements that have been set and the use of effective and efficient resources.

This is intended so that the development process of a project can proceed smoothly in accordance with the budget (budget) have been determined. A budget is a financial plan that includes estimated expenditure as proposed and expected sources of revenue to fund it in a certain period of time [7]. The preparation of the budget made by the construction company called the budget plan (RAP) project. The preparation of the budget is the amount of the cost of the benchmark used by the company in determining the material purchase payment of wages and other costs that go into the process of development activities project budget Plan also is one key to a very reliable company to set spending at the expense of the costs that will be incurred. As for the function of the budget plan the cost of development is made by construction companies, among others:

- Tthe general guidelines as a contractor to perform the contract agreement with sub-contractors or contractors.

- As a reference for price negotiations between general contractors with a foreman or subcontractors.

- To know the magnitude of the range of advantages and disadvantages which will be experienced contractors using a method of work.

- If it turns out that the estimated loss then contractors could soon be looking for a way to profit.

- As a basis for the schedule of arrival of materials and labor. 
Meizy Amariza \& Hadri Mulya., Sch Bull, Nov 2019; 5(11): 648-657

- To make the curve $\mathrm{S}$ but this schedule is usually made for the purposes of the contractor while the reports to supervisory or consultancy project owners remain bound to $\mathrm{RAB}[1]$.

The implementation of the operational construction management functions being performed is useful for the company. It can also help companies to do a benchmark against the level of effectiveness and efficiency in terms of the use of the budget of the project. Effectiveness is very important in measurement or comparison between the resulting output against input used as well as related to the relationship between the expected results with the actual results achieved. Effectiveness is how well the work that has been performed, the extent to which people produce output as expected [8]. If a job can be completed by planning, both in times, cost and quality, it can be said to be effective. Efficiency is related to the relationship between output in the form of goods or services produced with the resources used to produce the output [9].

To achieve the level of success where its implementation is done in conjunction with the implementation of the internal control system (SPI) are concerned with optimally in order to avoid failures in the execution of the construction. The system of internal control is an integral process of actions and activities performed by management (Executive) and would like to give an assurance or confidence that the top goal of adequate organization through effective activities and efficiency, reliability, financial reporting, safeguarding State assets and observance of laws and regulations. The "Hasanah \& Fauizi [10]. The company's failure in performing the implementation of internal control of the system will also have an impact on the quality of the financial statements of the company. From these three aspects that have been spelled out where the successes and failures of the above aspects will have an impact on the quality of the financial statements of the company.

The financial report is a report compiled systematically concerning the financial position of an entity at a particular moment and the performance of an entity at a particular period [11]. Financial report describes (a) the achievement of the program's performance and activities, (b) the progress of realization of the attainment of target income, (c) realisation of absorption of shopping, and (d) the realization of the financing. To find out the range of benefits that accrues to the company. The senses [12]. The qualitative characteristics of financial statements are a measure of the size of the Normative needs to be realized in accounting information so that it can meet its goals. The following four characteristics are normative prerequisites that are needed so that government financial reports can meet the desired quality: 1)
Relevant, 2) Reliable, 3) Can be compared; 4) Can be understood [13].

\section{The outline of the research issues}

- How the role of operations management in a construction company?

- Does management functions can run as expected?

- What is the process of building construction runs by effectiveness and efficiency in the use of the budget of the project by the company?

- How the application of the system of internal control of the company?

- How the results of the final process the role of construction management functions, Efficiency in the use of \& Effektifitas project budgets as well as the application of the system of internal controls against financial statements?

\section{The purpose of the research goals of this research} are as follows

- To know the role of the operational management functions in the construction company.

- To know the process management functions are run in accordance with the diharapkankan.

- To know the process effectiveness and efficiency in the use of project budgets in the company can already go well

- To know us the role of the application of the system of internal control in a company.

- To find out whether the failure of the 3 aspects above has an impact on the quality of the company's financial statements.

\section{THE CORNERSTONE OF THE THEORY Theory of Planned Behavior}

Planned Behavior Theory explains the behavior of individuals that arise due to the intention of the individual to behave and the intention of the individual is caused by several internal and external factors of the individual. Individual attitudes towards behavior include beliefs about a behavior, evaluation of behavioral results, subjective norms, normative beliefs and motivation to obey. Humans are social beings. This shows that humans live side by side with other humans. Someone will need other people in carrying out their lives. Behavior shown by someone will also affect the behavior of others.

\section{Component of Planned Behavior Theory}

This theory is based on the assumption that humans are rational beings who always take into account the implications of their actions before deciding to do a behavior they will do. In the theory of planned behavior it explains that the intention of the individual to behave is defined by three components, namely:

- Attitude towards the Behaviour (Attitude toward Behavior) behavior is not Attitude; $n$ Amun attitude presents preparedness for acts that lead to behavior [14]. 
- The perception of control behavior (Perceived Behavior Control) behaves In an individual not be able to fully control his behavior under the control of the individual or in a condition can be otherwise where an individual can controlling his behavior under the control of the individual.

- Subjective Norms (Subjective Norm)

- An individual will perform particular behaviours if his behavior acceptable to those it thinks are important in their lives can accept what is going to do. So, the norms established people around the individual who will be influential in decisionmaking (normative beliefes) generate awareness of pressure from the social environment or Subjective Norms.

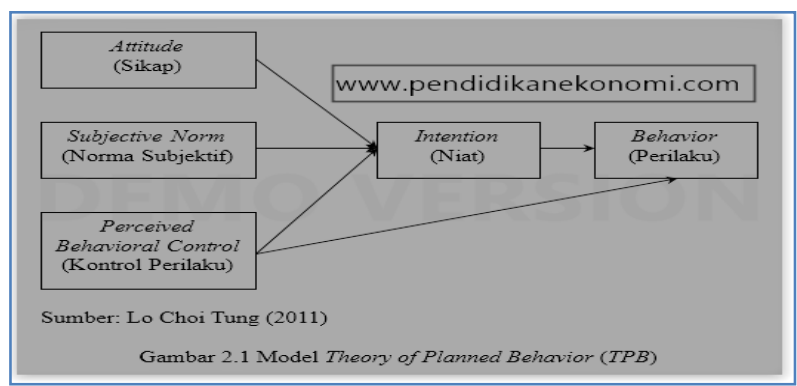

Fig-1: Model Theory of Planned Behaviour (TPB)

The theory of planned behavior to load the beliefs influence on attitudes towards a particular behaviours on subjective norms, and control behavior that we appreciate it. All of these components interact and become a major factor for intensi which in time will show whether the planned behavior will be done or not.

\section{The Relationship of the Theory of Planned Behavior (Theory of Planned Behavior) and Research}

The intention to perform a behavior will lead to one's mindset in determining whether he is going to do or not to do a job. Intention can also affect someone in conduct that in his life, as far as intention owned can affect someone for being able to behave well or conduct that is not good. The magnitude of the intentions which belonged to someone in conduct that may also affect others in being. The theory of planned behavior can be used to estimate or predict a person's intention to work on something related to the activities of his work. The variables used in this study fall into the invalid constructs that exist in the theory of planned behavior and theory of reasonned action. The background relating to the person's level of religiosity is the nature of personality. A person's level of religiosity can be measured and seen from one's obedience in doing a job that has to do with worship. The level of religiosity that owned one can affect the interests and intentions of a person against an occupation or activity. The background is also related to the level of knowledge and control of one's belief in the Theory of planned behavior because knowledge is one of the factors that can affect a person's behavior or actions. Control belief related to the belief that a behavior or. job can be done for example in the research level of knowledge belonging to someone in the mastery of a field of work performed will get results satisfying personally or to be social.

The perception of the ability of control (perceived behavioral control), is the belief that someone never done or never did a particular behaviours. The perception of belonging to a person against something can be divided into two good and bad. Good and bad behavior that is capable of influencing attitudes, interests or intentions of a person to do so. Financial satisfaction with regard to the consideration of a person against the implications the implications of the action that will be performed. Financial satisfaction is one benchmark that dibisa make someone able to do an Act whether it be good or bad.

\section{REVIEW OF THE LITERATURE Construction projects construction}

The construction project carried out by the contractor is an activity obtained from a tender that is carried out in a short period of time in accordance with the time set. The results of these activities are unique results said to be unique because they involve a large number of resources that must have their own specifications Construction projects are a series of activities that are only once carried out and are generally short-term involving large resources and must have specifications There are 3 characteristics in the construction project [11] contained in the form of images, namely:

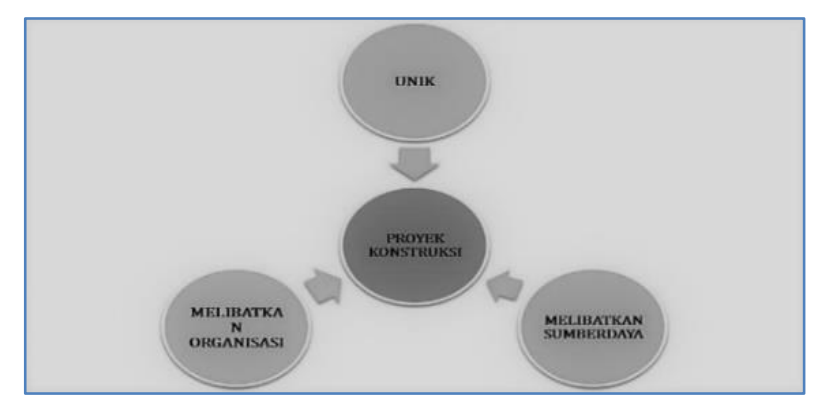

The characteristics of the project above are known as the Tradeoff Triangle or Triple Constraints. Triple Constraints are efforts to achieve goals based on boundaries.

\section{THE DESIGN AND RESEARCH METHODS}

In the study researchers here use this type of quantitative research which are descriptive analtik in which researchers more emphasis to the objective phenomena and phenomena being observed naturally. This research is research that aims to explain phenomena using figures for mencandarkan characteristics of individuals or groups [15]. This study assesses the nature of the conditions. In this study the researchers obtained data on the basis of observation, 
document analysis, and field notes, compiled research on site researchers to look at the phenomena that occur in the real, where the results of the research have been obtained later is not poured in the shapes and figures. The only instruments used in this study are its own researchers, data obtained through observation, interviews, and documentation.

\section{The Method of Data Collection}

The data gathered by this study is based on primary data and secondary data. Primary data obtained from field research, including interviews and observations with the Site Manager Project and the parties involved in the implementation process of development. Observation and Documentation in-depth Interviews (In depth Interview). Data collection is obtained by means of the method of doing a series of data collection by Creswell. This data collection methods do researcher's start from obeservations, in depth interview with the documentation are obtainable. Interview conducted by researchers to get confirmation directly from some of the questions that have been collected during the process of data collection. Observation is a method that is done by making observations on the situations and conditions, and the phenomena that occur during the process of research were done. Documentation is one of the early stages and it is important for researchers after making observation and interview. As for some of the options, benefits, and limitations in performing a series of.

This method according to Creswell is served through the table below:

\begin{tabular}{|c|c|c|c|}
\hline $\begin{array}{l}\text { The type of data } \\
\text { collection }\end{array}$ & Options based on the Type & Benefits based on type & Restrictions based on type \\
\hline \multirow[t]{4}{*}{ Observation } & $\begin{array}{l}\text { Participants Complete-the role } \\
\text { of the researcher is hidden }\end{array}$ & $\begin{array}{l}\text { Researchers have firsthand } \\
\text { experience of the } \\
\text { participants }\end{array}$ & $\begin{array}{l}\text { The researcher was } \\
\text { impressed intrusive } \\
\text { (boring/annoying) }\end{array}$ \\
\hline & $\begin{array}{l}\text { Observer as Participant- } \\
\text { researcher Role unknown }\end{array}$ & $\begin{array}{l}\text { Researchers can record } \\
\text { informational events }\end{array}$ & $\begin{array}{l}\text { Confidential information } \\
\text { may be revealed but could } \\
\text { not be reported by } \\
\text { researchers }\end{array}$ \\
\hline & $\begin{array}{l}\text { Participant as Observer- } \\
\text { Functions secondary functions } \\
\text { against observations of } \\
\text { participants }\end{array}$ & $\begin{array}{l}\text { Aspects of the unusual can } \\
\text { appear during the process } \\
\text { of observation }\end{array}$ & $\begin{array}{l}\text { Researchers may not have } \\
\text { ability and a good presence }\end{array}$ \\
\hline & $\begin{array}{l}\text { The full observer-Researchers } \\
\text { conduct observations without } \\
\text { being involved at all }\end{array}$ & $\begin{array}{l}\text { Useful for corporate topics } \\
\text { that may not be comfortable } \\
\text { discussed by participants }\end{array}$ & $\begin{array}{l}\text { Several groups of } \\
\text { participants can exhibit a } \\
\text { special issue }\end{array}$ \\
\hline \multirow[t]{4}{*}{ Interview } & $\begin{array}{l}\text { Face-to-face, one-on-one, in } \\
\text { person interview }\end{array}$ & $\begin{array}{l}\text { Useful for corporate topics } \\
\text { that may not be comfortable } \\
\text { discussed by participants }\end{array}$ & $\begin{array}{l}\text { Present information not } \\
\text { filtered directly due to the } \\
\text { perspective of participants }\end{array}$ \\
\hline & Interview By Phone & $\begin{array}{l}\text { Participants can provide } \\
\text { information in historikal }\end{array}$ & $\begin{array}{l}\text { Present information based } \\
\text { on a place that has been } \\
\text { arranged, not based on the } \\
\text { State of the natural }\end{array}$ \\
\hline & $\begin{array}{l}\text { Focus group researchers } \\
\text { interviewed participants in the } \\
\text { form of a group }\end{array}$ & $\begin{array}{l}\text { Make free researchers } \\
\text { control the flow of } \\
\text { questions }\end{array}$ & $\begin{array}{l}\text { The presence of researchers } \\
\text { can impact bias for } \\
\text { participants }\end{array}$ \\
\hline & Email and Internet interviews & & $\begin{array}{l}\text { Not everyone has the same } \\
\text { point of view }\end{array}$ \\
\hline
\end{tabular}

\section{METHODS OF ANALYSIS}

These studies use quantitative methods with descriptive analysis because the data were analyzed in depth interviews, obtained from and direct observation, the situation with the parties concerned in the process of project development and implementation with see the occurred phenomena in field and observe the situation and circumstances during the process of research is underway, The data that has been obtained is analyzed with the aim of simplifying the data into a form that is easier to read and interpret and then draw conclusions.
The conclusion must be agreed upon by the researcher and the research subject. Data collection conducted by the researcher in the qualitative research can be obtained for the beginning of the research process and data storage according to Mulya et al. [10]. 
Meizy Amariza \& Hadri Mulya., Sch Bull, Nov 2019; 5(11): 648-657

RESULTS AND DISCUSSION

The reality of the Kebertahanan Company in his 39 years as an Indicator of Reinforcement theory

\section{The Functions of the Management Dynamics Project Management}

Travel companies are experiencing the dynamics when viewed from the theory should be. This means that companies in the management of the project has many penyimpagan deviations and weaknesses of weaknesses in the management of opersionalnya. The weakness among the weaknesses associated with:

\section{The Role of Operations Management in the Construction Enterprises}

The company still has not considered that the role of management operating in important companies. This happens because of the unfamiliarity of the religious factor in the management of operating management roles in the implementation itself. If the company's management understands in theory what is the purpose of role management operating here then it can help them to determine the required strategy measures in the decision-making process as long as they refer to in management of integration, in which they define the main elements as scheduling, budgeting and costing, configuration management, and documentation[5].

Based on the theory of the purpose of the application of management operating here if studied and known in detail there are 5 aspects that will help companies in doing action efficiency, make improvements to productivitas and completes on schedule for the maturation of the economy, as well as the implementation of the reduced processing time in opimal so that the results obtained will be very maximal. Of the 5 aspects contained in the above benefit is also a key to success for the company in the achievement of the mission and vision in accordance with the planning. The company indicated weakness resulting from the negligence of this operational management role, not visible from the passing of a number of aspects related to the implementation of the construction activities. As for 5 (five) aspect of the purpose of the application of the operational management of the company has not done here in both aspects of the above aspects include:

\section{Efficiency}

The company's steps in making efficiency are still not perfect. The new company can determine how many workers are involved in the process of completing the project while in the implementation of procedures working hours and placement of employees in the profession is still not appropriate so that there are some error errors in this case such mistakes include: The first mistake the company made when doing the process of placing employees and labor. The placement of employees and labor is not in accordance with the profession and expertise they have. Second Mistake Providing working hours to employees who do not comply with work standards, where the company gives freedom for employees to overtime exceed the working hours and the implementation is carried out without supervision. So as to make employees free to record overtime work at will. This greatly affects the payment of wages at the end of the month where the cost of paying wages for labor is included in the calculation of a BOQ of $30 \%$ if the expenditure over the wages exceeds the limit specified in the BOQ.

\section{Productivity}

The company's steps taken in productivitas can be seen from the increased maturity of the company in calculating exactly how large the amount of labor that will be absorbed by the company in the process of completion of the work here. Payment of wages over the workforce was also able to increase the productivity of the company in the achievement of the maximal profit. Increased productivity measures in the implementation of operational management here can also be made of the company by increasing accuracy in determining quantity and completes on schedule in the purchases of materials and materials which will be used in the process. This development is. In the increased productivity the company could still not here do well this gives rise to the occurrence of some errors: error first mistakes the company has had in increasing productivity this budget spending activities have not gone well. This can be seen at the time purchasing product selection bag material and determine the quatity needed. Error in determining the amount of the quantity often occur where this occurs is caused because middle managers less noticed any change spec and volume at a time when there is a change in the design of the image. the excess amount in the determination of quantity occur also because of lack of communication between related parties, the situation with the purchasing so that purchase order over the top publishing material often does not fit even more than the specified number of in the Bill of Quantity (BOQ). The second error: at the time of expenditure over the material often bag purchasing forgot to add and perform calculations for the costs of shipping the material. Understanding purchasing over the bag material is also not well understood. Parts purchasing selected and placed by Liability Company is not from the people who understand the types and type materials (e.g. iron in the purchase there is usually a cost addition of connective or rolls), so the delivery of materials is often done repeatedly, this would be the addition of unexpected costs for the company.

\section{The Economy}

Before entering the stage of using the project cost budget, the company has already determined the amount of costs to be used during the construction 
Meizy Amariza \& Hadri Mulya., Sch Bull, Nov 2019; 5(11): 648-657

project. This is done by implementing a project budget plan that is commonly referred to (RAP). Preparation of the budget is done before the project runs. The purpose of this arrangement is so that the company can easily find out how much it will cost to complete the work and to find out how much profit will be obtained. Although this step has been carried out by the company, but in the implementation in the field it still has not gone well. The use of project budgets is often not in accordance with previous planning. It does not fit between the use of the budget and its preparation can be seen from several items in the bill of quantity that have not appeared or are still lacking in the description. The lack of details of items included in BQ causes unexpected costs to be incurred as an additional expense in the expenditure. Examples of unexpected costs that appear to be additional costs in spending.

- The cost of the iron Fastenings at the time of delivery.

- The cost of shipping the addition over the wrong material in the calculation of the volume of

- Operating expenses

- The cost of making the asuansi for the project at the time of planning, based solely on estimates of the estimator, not based on\% set by the insurers or banks in accordance with the quantity value of the agreed project.

Due to the advent of fees above indicates that the presence of telitian in the preparation of the budget of a project conducted by a team of estimator and a lack of communication between some divisions in the determination of fees that will be incurred. Management (with the purchasing, management with the bag-making bank guarantees or insurance project).

\section{Management Functions within the Company}

Based on the results of the reviews and observations made by researchers for the period of 2009 until now, in reality the company has not carried out the construction management function properly. This can be seen from the side:

\section{Planning (Planning)}

The planning company does look already matured enough but in fact during the implementation of the companies still do not implement it properly. This can be seen from some of the implementation of the plan has been compiled but at the time of its implementation did not go well:

\section{Review of implementation methods of work regarding the terms K3LMP (health, safety, environment, quality and security)}

In meeting the standards of health care work and company employees, they have provided insurance for BPJS and CAR. For work safety the company has provided a complete range of standard equipment or equipment which must be fulfilled and used during the process of completing work such as helmet projects, boat shoes, project shirts, and others. However, when the project took place the tool was often overlooked because the company did not supervise to directly monitor the use of K3LMP so that there were still workers who did not use work safety standards so that they could cause problems in the process of completing the work.

\section{Implementation of the Aspects contained in the stages of planning activities \\ In the implementation of aspects of the} planning activities of the company here has not been executing well stages include:

\section{Analyze the aspects of project feasibility Study on Market Property}

In the process of the activity of the company is not doing reviewing survey directly into the factory or store the material so that the company does not have a list price of material including a update (latest) so that companies less aware of any material price change. Parts purchasing less deft in reporting rates or in conducting activities that directly relate to the purchase and booking of the goods. This led to the company often times get a high price in spending. From the error above also makes the company less exclusive communication relationship and intent against the marketing of regular old penyupply trade with the company. Parts purchasing often switch replace supplier just to get the new price. Whereas according to the researcher's point of view it would be more worthwhile companies remain in a relationship of cooperation with suppliers and long it is intended they better understand the payment system that is commonly done by the finance of the company. Establish new relationships with new suppliers don't blame if only purchasing party more deftly toward an emphasis of the process the payout later. The price of the new company could indeed be a bit cheaper but in the process the payment they always want payment upfront payment by COD (Cash on Delivery) this is a very troubling passage of cash flow of the company. Because the company ever got paid for bills the project based on the progress of work or based on terms which have been tailored to the employment contract or the SPK has been published by the owners.

\section{Analyze the Feasibility Study on the financial aspects of the property}

In the process of carrying out analysis in terms of financial aspects here also still experience some obstacles this occurs because there is no supervision in the use of funds. Planning of the budget that has been made there several times that is not in accordance with the initial planning. The first mistake seen in making insurance on the project, where the budget for making project insurance here is not included in the preparation 
Meizy Amariza \& Hadri Mulya., Sch Bull, Nov 2019; 5(11): 648-657

of the project budget plan. So when the making of insurance for the project requested by the owners is not implemented and is less realized. Second mistake: At the time of material purchase there has been a discrepancy with the volume. Where the purchase of material exceeds the calculation of the existing volume. This causes the company to spend more on the expenditure. Some of the above errors cause the existing cash flow to be incompatible with the initial budget plan.

\section{Analyze the aspects of project feasibility Study in Management Property}

Management Aspects in analysis here is still running the company:

- The company has not been able to redeploy employees in accordance with the profession.

- Implementation of the preparation of the company's organization structure for the project is still not running properly

\section{Organizing (Organizing)}

Organizing system in DIC image already composed correctly, both the establishment of the organizational structure for management and establishment of the organizational structure of the project. However, in the exercise of the profession and the placement of employees is still very inconsistent with his experience and his expertise. Organizational structure the company formed the company management based on the results of the meeting was already arranged. But in practice the formation of an internal project organizational structure had occurred. Where this formation occurs because of the purpose of personal interests. From the formation of the organizational structure the parties concerned can already predict the range of maximum profits that will be obtained from the implementation of the construction project. The maximum profit amount that can be obtained can reach the range of $30 \%$ to $45 \%$ of the value of profit that should be received by the company.

\section{Lead (Leading)}

Based on the theory of management function here concerns the coaching and motivating subordinates to achieve the main goals can affect individuals or teams while working. Communication is an effective channel and can help solve problems. In the application of management functions in a practitioner according to the results of the research the lead category with the things mentioned above has never been done by the company and its application is felt to be still very minimal. Leadership is a decision that is more the result of a process leading to a change of character.

\section{Control (Controlling)}

Based on the observations of the researchers control systems in the company is very less. This happens because the company does not undertake the formation of a special team to conduct control over various activities during project implementation progress. So that irregularities frequently occurred during the construction process. The absence of a control team working to conduct monitoring activities during the execution of the construction took place led to some peyimpangan and determination of a violation of the procedure prescribed by the management team. Does not the passage of control systems here also have an impact on the implementation of the activities that had no cover from the function of the control itself? The activities of the control consists of a. b. Supervision and Inspections c. Reporting

\section{The Power Management System Project Management}

\section{The company's survival for 39 years until now}

Project management system performed the management have a variety of drawbacks if compared with the existing theory right as explained earlier. However, the weakness of the weakness that is contrary to the theories of operations does not cause the occurrence of bankruptcy over the existence of the company proving that the management company has the power the power outside of the context of the theory, this proved to be bertahannya company for 39 years even though my observations in the 2012 time frame up to now. It can be concluded that the strength of the company's owned is a concept of reality from happening. The concept of reality that is happening from my observations is portpolio project.

\section{Management Protofolio}

The company in running wheel business as a consulting company using the concept of the portopolio project. The concept of this project is the portopolio action to earn as much as the large number of projects in accordance with the company's strengths so that in the development of the system of mutual covered the losses could make companies endure. The peusahaan received the project could reach $4-6$ of the project Owners. Where the project earned value project that is so high that the company's profits could reach the level of maximal. The losses experienced by the company of some of the existing projects can be covered from profit project to another. Then these companies only profit achievement-oriented and berfocus on timeliness in the process of project implementation. The second factor above that caused the company to easily ignore the prevailing theory application in construction. If the application of the theory in the implementation of the construction was performed by berusahaan well at least many companies could do the anticipation for any loss which may arise from it. And the achievement of profit can be maximal again. 
Meizy Amariza \& Hadri Mulya., Sch Bull, Nov 2019; 5(11): 648-657

A Good Relationship is One Indicator That a Company Endures into Power

In addition to the management system of the company-run portpolio to persist in running its business in the field of wheel construction. The company also has a very close relationship with related parties. This is apparent from the Ministry and services given the company is very good. So that raises a huge sense of satisfaction on behalf of the interested parties or stakeholders in the development process. Ownership of the relationship are interwoven to the extent the relationship aspects of work related to the development of the construction.

Some compelling reasons so that from the year 2009 to the present dikarena some things below

- The company has had a complete Legality that was in accordance with the applicable rules of construction.

- The value of the acquired projects is in compliance with the agreement signed by the two sides that unravel in the contract of employment

- Consistent properties owned by companies in the precision in the implementation time is always in accordance with the Time Schedule agreed upon.

- Completes on schedule of Goods used in the Construction were in accordance with the request of the Owners.

- Communication: implementing Team is always a good communication relationship with various related parties.

- $\quad$ Service: the granting of service given to the owners of the company can be said to be satisfactory. By looking at the results of a given company reporting to the owner complete starts from the creation of weekly reports, monthly reports, survey results until test results test of product that is required to do the test.

\section{SUMMARY AND ADVICE CONCLUSIONS}

This research was conducted based on the elaboration of some of the problems that arise in the company. From the results of research that has been done then one by one from the problems that have arisen from the start have produced answers, researchers can deduce from various stages in data collection. As for the conclusions that will be elaborated to describe researchers in accordance with each formulation of existing problems, namely:

\section{The Role of Operations Management in Construction Companies}

Operational management role in companies here do not have an important role for the company in the process of the implementation of the kegaiatan Construction Company is more oriented on the profit to be taken alone.

\section{The Function of Management in Construction}

The management function in the company has not run properly. This results in many problems arising from each stage and step of the activity in the process of implementing the construction. Of the four elements in the existing management functions the company only does a few sub-divisions including planning. Planning that has been made by the company is in accordance with what was previously planned. The elements of the operational management function about organizing have been established by the company so that it appears in the organizational structure of the company. In the organizational structure of this company has been described who is authorized to carry out delegation and responsibility.

Of the four management functions that exist the new company carries out just one element so that the three elements of the existing management functions are still neglected so that some problems arise that must be faced by the company.

\section{Assess corporate effectiveness and efficiency in the use of the budget of the project}

Effectiveness and efficiency in the use of project budgets in felt perfectly yet it relates to the application of the system of control and supervision on the company did not go well. How can penerpaan on the control system it goes well if the company does not have a special team to conduct the control. The new application can be felt and executed properly if there are actions that are hand-made to align clients ' vision and mission management. To the three elements of such action is the key for companies to monitor and supervise the use of funds also have been teralokasi for financing of the project.

\section{Assessment of the implementation of the Internal Control System in Enterprises}

The company has not been able to implement the internal control system if the important things from the implementation of management, management functions and action activities from control here are still not going well. The idea that is only oriented to the final profit makes the company not pay attention to what should be more important because this has more impact on the sustainability of the company in the future. The neglect of what should have an effect on the sustainability and position of the company's cash flow will have more adverse effects on the company which will affect the condition of the financial statements for a long period of time

\section{SUGGESTIONS}

The company must carry out the operational management functions of the construction properly. The deficiencies in the elements of the management function of organizing function here should get special attention from the management team to begin 
Meizy Amariza \& Hadri Mulya., Sch Bull, Nov 2019; 5(11): 648-657

implementing a system for controlling and monitoring during the development process and in the implementation of form a team specific to each implementation process construction and placing personnel managing personnel in accordance with the profession and his experience in order to avoid errors in the completion of the construction work. The company shall hold meetings more frequently intern with the entire staff to get a special note from each Division to make improvements repairs in determining the new measures more strategies for the achievement of the target profit more maximal for the company.

- For the assessment of the effectiveness and efficiency of the firm in the use of project budgets can be achieved in accordance with the targets that have been planned and organized then the company should do the analysis of the causes of the causes that give rise to the existence of the lapses occurred that might be a big problem for the sustainability of the company and the company shall immediately take action activity that includes among its activities on control action of supervision, inspection actions (actions correction) and the Act of reporting and try all in accordance with the procedure set by the top manager and management company. The action of the control activities if carried out could help the company overall in detecting problems and irregularities that might arise a result of hacking up the authority and responsibility that has been given.

- The application of the system of internal control in a company should be done in order to make it easier for companies to conduct inspections of action on deviations that occur. The formation of a special Team that is associated with the control should be immediately formed and run this makes it easy for companies to better monitor all personnel of various levels either. Starting from the Middle Manager, Site Project approaches, employees as well as personnel related personnel in the process of project development activities. Start to run the role management, management functions and the application of control systems properly to get the changes in various aspects of the activities, especially at the end of the achievement of the completion of the development process.

- The final process of construction management function, the role of the effectiveness in the use of budget Efficiency \& project as well as the implementation of internal control system against new financial report results could look if the company can soon do the Act of correction of any problems arising the company. The Act of correction should be done with the parse notes that have been made and in the note in detail regarding the handling of the Corrections Act. From existing record companies can merarik the conclusion of what has been created and can be used as ingredients in decision-making to determine next steps relating to the activities or processes related to improvements in the position of the year-end financial statements.

\section{REFFERENCE}

1. Marzuki, C. C., Salman, A. N. M., \& Miller, M. (2013). On the total irregularity strength of cycles and paths. Far East Journal of Mathematical Sciences, 82(1), 1.

2. Dimyati, H., \& Nurjaman, K. (2014). Manajemen proyek. Pustaka Setia, Bandung.

3. Stoner, A., James, F., Edward, R.F., \& Daniel, G. (2016). Management (6th ed.). New York: Pearsen Education.

4. Ricky, W. G. (2013). Contructions Management (11thed). South Western - Cengage Learning

5. Sevilary, Demirkesen, B.O. (2017). Impact of Integration Management Concruction Project Management Performance. International Journal of Project Management, 35: 1639-1654

6. Keoki, S.S., \& Glenn, S. Contruction area Project Management (5th ed.). Richard H. Clough.

7. Hasbi, H., \& Haruman, T. (2010). Banking; according to islamic syaria concepts and its performance in indonesia.

8. Winoto Y.D.A. (2014). Construction Management for the Building. Intan Pariwara.

9. Robert r. Moeller, Second edition. (2011). COSO enterprise risk management: Establishing governance, risk and compliance processes - the Library of Congress Cataloging in Publication Data.

10. Mulya, H., Sukoharsono, E. G., Djamhuri, A., Zaki, B. (2016). Qualitative Research methods in accounting Sultan Syarif Kasim Era Treasure Kingdom of Siak Sri Indrapura Riau (1908 - 1986). Jakarta: Media Discourse Partners.

11. Ervianto, I. W. (2013). Construction project management (p. 11-22) revised edition. Yogyakarta: Andi Offset

12. Babatunde, A. A., \& Akeju, J. B. (2016). The Impact of Corporate Governance on Firms' Profitability in Nigeria. International Journal of Business and Management Invention, 5(8), 1-5.

13. Mursyidi, A. (2013). The role of analytical chemistry in Halal certification. Journal of Food and Pharmaceutical Sciences, 1(1), 1-4.

14. Lubis, A. I. (2010). Akuntansi keperilakuan. Jakarta: Salemba Empat.

15. Chandra, S. (2014). Maximizing Construction Project and Investment Budget Efficiency with Value Engineering. PT Elex Media Komputindo. 